\title{
The Impact of Innovation on Customer Satisfaction: A Study of the Cosmetics Producer in Tehran
}

\section{Gholamreza Askarpour Daragahi ${ }^{31}$}

\begin{abstract}
Nowadays customer satisfaction is one of the basic requirements of manufacturing companies in developing countries. This study was conducted to investigate the effect of innovation in product presentation on customer satisfaction. The statistical population includes the customers of cosmetics produced by ten companies in Iran. The simple random sampling method was used to select 387 individuals. The results indicated that innovation in product presentation had a positive effect on the satisfaction of customers consuming cosmetics. In this study, open innovation and closed innovation paradigms were employed to deal with the main research problem.
\end{abstract}

KEY WORDS: Open innovation, Closed innovation, Cosmetics, Customer satisfaction

JEL: M37, L66,031

UDC: 659.127 .6

005.591.61:334.7(551)

COBISS.SR-ID 238313740

${ }^{31}$ Department of Management, hormozgan branch,Islamic Azad University,hormozgan,Iran 


\section{INTRODUCTION}

Nowadays the companies adopting innovation use internal and external technology resources to empower their businesses. Innovation is a key element in the success of companies in a competitive environment (Wang, Zhao, Voss, 2016). Innovations begin with innovative ideas. Therefore, the primary activities of an innovation process should be involved in a systematic approach to access information from different sources (Buijs, 2007). Customers are regarded as the most important source of innovative ideas in the process of a new product. Companies can take advantage of them. In recent years, the importance of innovation has been on the rise because consumers demand diverse products of producers gradually. Moreover, innovation maintains and expand the position of a company in the market (Baldassarre et al, 2017; Baldassarre et al, 2017). The dynamism of innovation systems is achieved through the evolution of innovation capability and absorptive capacity at the same time (Elad, Koski, 2010). Furthermore, the dynamism of innovation capacity results in the sustainable growth of absorptive capacity because innovative and investment activities increase the ability to emulate success, and resources are used in technological activities (Trejo, Gutiérrez,Guzman, 2016; Barasa, et al. 2017). The evolution of absorptive capacity stabilizes innovation dynamism by increasing productivity especially in customer-related activities and adherence to technological activities. Innovation influences the business model of a company and enables the company gain values from not only its own business, but also the businesses of other companies by using key assets, resources or opportunities (Galloway et al, 2017; Saebi, Foss, 2016). The effects of this approach include decreasing the cost and time of developing a new product resulting from the sales of technologies not used by a company and creating spin-off firms (Gundy et al. 2011). The success of all manufacturing, service, profit, non-profit, public, and private companies is influenced by various factors, one of the most important of which is customer satisfaction to achieve business excellence (Pulles et al. 2016). Customer satisfaction has become an important research subject in sociology, psychology, planning, marketing and geography. Satisfied customers are less price-sensitive. They are less often influenced by rivals. They also remain loyal to the company for a long time. Therefore, companies need to control and improve customer satisfaction to maintain their customers. Traditionally, managerial and research efforts are focused on the concept of customer satisfaction, and business leaders try to adopt it in their companies (Navimipour, Soltani, 2016). Customer satisfaction expresses a modern approach to quality in economic institutes and organizations as well as the creation of a real customerorientation management and culture. Measuring customer satisfaction results in an instant, significant and objective feedback regarding customer expectations and priorities (Mortara, 2009). Customer satisfaction is one of the most important consequences pertaining to different trading organizations. It has been confirmed with the philosophy of customer-orientation and the main concepts of sustainable improvement (Galloway et al, 2017). Therefore, it should be evaluated and divided into some measurable parameters. Satisfaction should not be regarded as the only goal of marketing. Moreover, previous studies indicate that customer satisfaction, word of mouth and customer loyalty are completely different structures (Maurya, 2015). In the past, the majority of studies on customer satisfaction emphasized the experience of consuming a product or encountering with services. However, most of these studies concentrated on cumulative satisfaction which is defined as the entire experience of a customer with a service or product provider. This approach to satisfaction presents a comprehensive measure including customer consumption desirability and their consequent behaviors such as the processes of sales and after-sales services (Gerke et al, 2017). This comprehensive look at satisfaction forms customer satisfaction indicators. The aim of this study is to determine the effect of innovation in product presentation on customer satisfaction. This study was conducted on the consumers of cosmetics. In Iran, the market capitalization of cosmetics exceeded 4.6 billion dollars in 2016 due to extensive advertising and marketing and with respect to the young Iranian population as 
well as changes in the consumption patterns. According to the statistics published by Iran's Detergents, Health, and Cosmetics Association, there are 96 cosmetics manufacturing units in this association. Eight of these units produce perfumes, and one of them makes eyeliners. Four of them produce lipsticks, and eight others make hair colorants. Two units produce cheek shades, and two others make body gels. Furthermore, 33 units produce lotions and creams, and two others make hair remover creams. Two units produce nail polish, and six others make sun blocks. Finally, five units produce hand and face gels. The majority of cream-manufacturing units are located in Tehran. According to the investigations of innovation and customer satisfaction, few studies have been conducted on cosmetics. The aim of this study was to determine the effect of innovation in the presentation of cosmetics on customer satisfaction.

\section{THEORETICAL BACKGROUND}

\section{Customer satisfaction}

Various studies indicate that the cost of obtaining a new customer is five times the cost of maintaining current customers. It has also been pointed out that $1 \%$ reduction in customer satisfaction results in 5\% return on the capital of an organization. Customer satisfaction means that they are satisfied with how an organization behaves and provides services. In other words, the organization should succeed in attracting and maintaining customers. These satisfied customers expect higher quality in services and products as much as they spend more time and money (Iberahim et al. 2016). Generally, customer satisfaction is regarded as one of the most important factors influencing the formation of a customer's future intentions of purchase. Some studies concluded that companies should let go of market investigations, advertisements, and promotions to achieve customer satisfaction. Instead, they emphasize the development of appropriate infrastructures so that they can meet the needs of customers by providing appropriate products and services. Customers should be able to achieve real satisfaction through the perceived quality and value of products. Oliver described satisfaction as full customer submission. In fact, satisfaction results from customer judgement on how much the features of a product or service can meet customer expectations favorably. This definition highlights the evaluative nature of satisfaction by which customers specify whether a product, trademark or store can meet expectations (Zain, Saidu, 2016).

\section{Quality of Product}

Nowadays the quality of products manufactured by industrial factories has become a challenge for their market shares and customer satisfaction in the competitive world. Focus on customer needs means paying attention to the quality of products and services provided for customers. In the traditional paradigm, the quality of products is evaluated in the light of their physical features and attributes such as robustness and reliability. According to a new definition, quality is a degree to which a product matches customer expectations and presented specifications. Optimal quality refers to a level of quality which prevents costs from increasing without adding the value of products in addition to satisfy customers. Customer services include everything a customer does to satisfy customers and help them receive the greatest value of the products or services which they have purchased (Lun et al. 2016).

\section{Satisfaction with the Sales Process}

Nowadays understanding customer needs and expectations is not just limited to improving the quality. Pre-purchase and post-purchase processes influence customer satisfaction with the received product or services. Not only do successful organizations evaluate and monitor their customers in terms of the qualitative performance of a product or service, but they also regard 
sales and after-sales processes as effective. One of the important services influencing customer satisfaction with organizations is the process of selling products and services. During this process, it is very important to cover all the customer requirements and expectations to achieve the desired products and services in order to satisfy customers. According to the latest investigations conducted in Customer and Market Research Unit at Iran's Quality Inspection and Standard Company, customer satisfaction with sales processes has a direct effect on customer satisfaction with the quality of products and services. The correlation of this relationships was reported 0.67 ; therefore, the importance of satisfying customers in this process and the general effect it has on customer satisfaction is completely obvious (Girgenti et al. 2016).

\section{Satisfaction with After-Sales Services}

Many companies are aware of the fact that after-sales services result in loyalty and repurchase. However, these services should be meant to satisfy customers. In a very distant past, developed companies used historic resources such as innovation technology and economic scales to direct their efforts inside companies; therefore, they could find opportunities. However, nowadays the majority of developed companies have moved from internal focus to external focus which is on customers (Dvořáková, Faltejsková, 2016). All of these companies have realized that they cannot achieve success by having all the technical superiorities of the world unless they consider customer needs in the design and delivery of products and services. A very few number of organizations could produce and present successful products without understanding customer requirements and expectations. On the other hand, the majority of successful companies have achieved success by focusing customer requirements and expectations. Therefore, each company needs to identify customer requirements and expectations to survive the market. Measuring customer satisfaction is the most important tool to evaluate the performance of after-sales services at each company (Ling et al. 2016).

\section{Product Brand}

Nowadays customer satisfaction is very important to the managers of organizations. The survival of an organization depends on customer satisfaction which itself depends on the reflection of appropriate brand to customers. In other word, it is called the internal brand of an organization. Although investigating customer satisfaction is the central point of many investigations, the concept of internal brand and its effect on customer satisfaction is a new concept in customer-related investigations. Given the intense relationship of customer satisfaction with customer preservation and organizational profitability, the extraordinary importance of measuring it is clear (Wang et al. 2016).

\section{Innovation}

In the research literature, there are different definitions of innovation. Innovation is the foundation or presentation of value (Yuhan, Yun, 2009). Innovation includes the formation of an idea as well as the adoption and execution of new ideas in processes, products and services. Nowadays innovation has become more important after shortening the lifecycle of products and technologies used in them (Castellacci, Natera, 2011). However, innovation is no longer done in an organization in today's dynamic and sophisticated world, and it is beyond the organizational boundaries. Therefore, organizations are seeking knowledge, information and external partners as the valuable innovation sources (Ghosh, Kato, Morita, 2017).This has changed organizational approach from closed innovation to open innovation. Hamidani and Wirawan believe that innovation in product presentation results in the preservation and growth of manufacturing companies, something which finally lead to the social and economic growth and development of developing countries (Zubizarreta et al. 2017). 


\section{Closed Innovation}

In his long-lasting work, Henry Chesbrough investigated the paradigm of closed innovation and the resultant insight to organize industrial research and development activities as well as important trading achievements and successes. Closed innovation has practically been used by many large corporations, especially American corporations, in the twentieth century. For instance, Xerox established a research center park which brought many successes in the long term. This paradigm is based on an introverted approach which is greatly consistent with the knowledge environment of the early twentieth century (Monsef, Ismail, 2012).

\section{Open Innovation}

Open innovation is a term which was presented by Henry Chesbrough in 2003. It refers to the purposive use of knowledge inside and outside an organization to facilitate the internal innovation and develop the market for the external use of innovation. In the environment of open innovation, organizational boundaries are penetrable (Chesbrough et al. 2006). When Chesbrough published his book on open innovation, he rehabilitated the idea that external knowledge was one of the main elements of innovation improvement (Vanhaverbeke, 2006). Henry Chesbrough defines open innovation as a model based on the assumption that if companies wish to improve their technologies, they can and must take advantage of external ideas such in the same way as internal ideas (Dahlander, Gann, 2007). They should also take diverse internal and external paths towards the market. Organizations have realized that they need to find new ways of identifying their requirements to develop specialties and communicational networks with individuals and institutions both inside and outside the organization. The ability of companies to achieve new technologies and match them with customer requirements provides new profitable opportunities for all companies (Spithoven, Clarysse, Knockaert, 2010). The internal knowledge required for such processes is valuable to companies. This knowledge should be protected to acquire competitive scores in the innovation processes of companies. Open innovation is meant to develop data, knowledge and human resources beyond organizational boundaries (Ades et al. 2013). New paths are required to enter the market of products with the combination of internal and external ideas in the architecture of systems. Open innovation paves these paths. Developing innovation, inspired by business models, results in the use of both internal and external resources of the organization to present value and definitions of internal mechanisms for creating value (Waiyawuthanapoom, Isckia, Danesghar, 2013; Lazzarotti, Manzini, 2009).

\section{RESEARCH METHODOLOGY}

\section{Research framework and hypotheses}

Figure 1. shows the research conceptual framework and hypotheses based on literature review. In this study, customer satisfaction is the dependent variable including the quality of products, satisfaction with the sales process, product brands, and satisfaction with after-sales services. Moreover, the independent variable is innovation including closed and open innovations. Four research hypotheses were introduced to achieve the research goals.

- Innovation has an effect on the quality of domestic cosmetics.

- Innovation has an effect on the sales process of domestic cosmetics.

- Innovation has an effect on the brand of domestic cosmetics.

- Innovation has an effect on satisfaction with after-sales services of domestic cosmetics. 


\section{Research design}

In accordance with the developed hypothesis the questionnaire constructed by referring to the previous research which focused on customer value through customer satisfaction. The questionnaire's purpose is to identify factors that influence customer satisfaction toward the producers of health products in Tehran Province. The main study questionnaires were collected. This study used a quantitative research design to:

- Determining the effect of innovation of the quality of cosmetics.

- Determining the effect of innovation on satisfaction with the sales process of cosmetics.

- Determining the effect of innovation on the brand of cosmetics.

- Determining the effect of innovation on satisfaction with after-sales process of cosmetics.

\section{Data collection and sampling}

The target population of this study were producers of health products in Tehran Province. Data was collected through online and asking respondent questionnaires for two months. A survey was conducted between $6^{\text {th }}$ October to $2^{\text {nd }}$ December 2016 and the questionnaires were filled out by respondents. The statistical population includes the consumers of cosmetics produced by 10 manufacturers in Tehran Province. The statistical sample includes 400 individuals to whom the questionnaire was distributed. After checking the completed questionnaires, 13 of them were not crossed out because they were not complete. Finally, 387 respondents were analyzed.

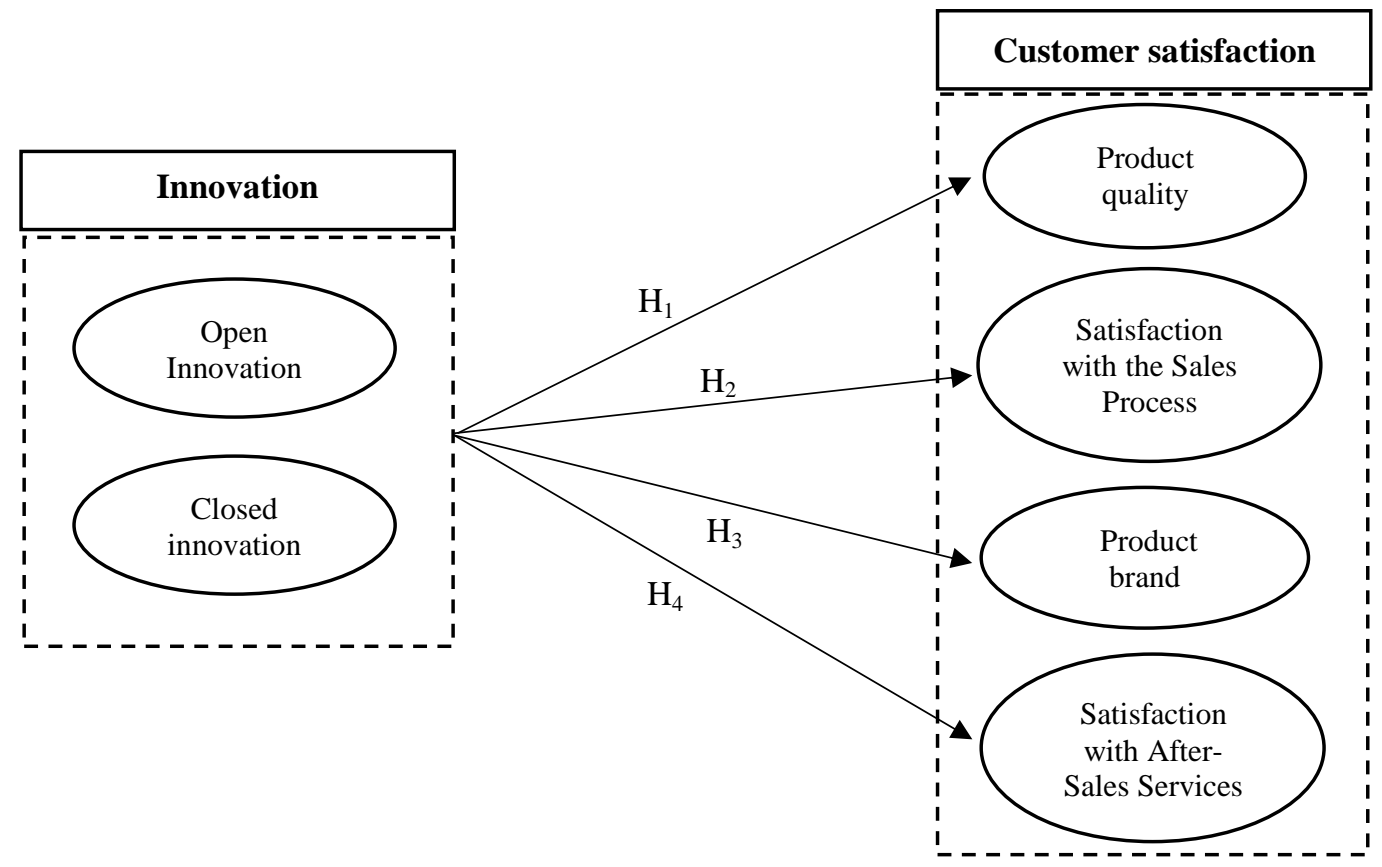

Figure 1: Conceptual framework. 


\section{DATA ANALYSIS AND DISCUSSION}

Figure 1. shows the statistical mean for variables:

Table 1: Mean and Standard Deviation

\begin{tabular}{|c|c|c|c||}
\hline Variables & Size of Sample & Mean & Standard Deviation \\
\hline Open Innovation & 387 & 1.878 & 0.505 \\
\hline Closed Innovation & 387 & 1.985 & 0.593 \\
\hline Innovation & 387 & 1.966 & 0.472 \\
\hline Quality of Product & 387 & 2.202 & 0.781 \\
\hline Satisfaction with the Sales Process & 387 & 2.215 & 0.753 \\
\hline Satisfaction with After-Sales Services & 387 & 2.160 & 0.799 \\
\hline Product Brand & 387 & 1.964 & 0.761 \\
\hline Customer satisfaction & 387 & 2.135 & 0.577 \\
\hline
\end{tabular}

This section investigates the relationships of corresponding variables, something which indicates the validity of items in the investigation of the intended variable.

The content validity measurement tool (expert opinion) and construct validity (confirmatory factor analysis) were used to confirm the validity of the measurement tool. Moreover, the output of LISREL was used to check the construct validity. The following table shows the factor load and significance coefficient of each item for each variable. It indicates whether the item is valid to evaluate the variable. In other words, the factor load indicates the correlation of each observer variable (items) with latent variables (factors). Therefore, the factor load and significance coefficient are investigated to evaluate each item.

Table 2: The Validity of Questionnaire Items

\begin{tabular}{|c|c|c|c|}
\hline & Items & Factor Load & t-Value \\
\hline 1 & \multirow{3}{*}{ Quality of Product } & 0.55 & 10.79 \\
\hline 2 & & 0.68 & 13.97 \\
\hline 3 & & 0.74 & 15.71 \\
\hline 4 & \multirow{5}{*}{ Satisfaction with the Sales Process } & 0.73 & 15.36 \\
\hline 5 & & 0.57 & 11.83 \\
\hline 6 & & 0.79 & 17.96 \\
\hline 7 & & 0.49 & 9.79 \\
\hline 8 & & 0.50 & 10.07 \\
\hline 9 & \multirow{6}{*}{ Satisfaction with After-Sales Services } & 0.65 & 13.86 \\
\hline 10 & & 0.38 & 7.54 \\
\hline 11 & & 0.39 & 7.85 \\
\hline 12 & & 0.66 & 12.44 \\
\hline 13 & & 0.77 & 16.50 \\
\hline 14 & & 0.83 & 18.27 \\
\hline 15 & \multirow{3}{*}{ Product Brand } & 0.51 & 9.96 \\
\hline 16 & & 0.78 & 17.29 \\
\hline 17 & & 0.76 & 16.73 \\
\hline 18 & \multirow{3}{*}{ Open Innovation } & 0.73 & 15.86 \\
\hline 19 & & 0.66 & 13.85 \\
\hline 20 & & 0.71 & 15.08 \\
\hline 21 & \multirow{4}{*}{ Closed Innovation } & 0.65 & 14.52 \\
\hline 22 & & 0.44 & 8.70 \\
\hline 23 & & 0.46 & 8.97 \\
\hline 24 & & 0.82 & 17.91 \\
\hline
\end{tabular}


The coefficient of determination $\left(\mathrm{R}^{2}\right)$, path coefficient, and significance coefficient were used to evaluate the structural model. In LISREL, the coefficient of determination is shown in the output. According to the following table, the explanation of variance and changes in dependent variables show the effect of independent variable (innovation). Moreover, innovation could explain $40 \%$ of changes in the quality of product, $44 \%$ of changes in satisfaction with the sales process, $70 \%$ of changes in satisfaction with the after-sales process, and $41 \%$ of changes in the product brand. In other words, it can be stated that one unit of change in innovation resulted in $0.40,0.44,0.70$ and 0.41 changes in the quality of product, satisfaction with the sales process, satisfaction with the after-sales process, and product brand. Furthermore, innovation could explain $65 \%$ of changes in customer satisfaction (quality of product, satisfaction with the sales process, satisfaction with the sales, and product brand).

Table 3: Coefficient of Determination $R^{2}$

\begin{tabular}{|l|c||}
\hline \multicolumn{1}{|c|}{ Constructs } & $\mathrm{R}^{2}$ \\
\hline Quality of Product & 0.40 \\
\hline Satisfaction with the Sales Process & 0.44 \\
\hline Satisfaction with After-Sales Services & 0.71 \\
\hline Product Brand & 0.41 \\
\hline Customer satisfaction & 0.65 \\
\hline
\end{tabular}

\section{Structural model testing}

According to the output of the conceptual model in the Appendix, the results of each hypothesis is separately described in a table. Then necessary explanations are given regarding each hypothesis.

\section{Hypothesis 1: Innovation has an effect on the quality of domestic cosmetics.}

Table 4: Hypothesis 1

\begin{tabular}{||c|c|c||}
\hline Hypothesis 1 & path coefficient & significance coefficient \\
\hline $\begin{array}{l}\text { Innovation has an effect on } \\
\text { the quality of domestic } \\
\text { cosmetics. }\end{array}$ & 0.63 & 10.96 \\
\hline
\end{tabular}

According to Table 4, it is clear that the path coefficient is 0.63 between innovation and the quality of product, something which shows the positive and direct effect of innovation on the quality of product. Moreover, the significance coefficient of these two variables is 10.96 (above 1.96) which indicates that the effect of innovation on the quality of product is significant at a 0.05 error level. Therefore, it can be stated that innovation has a positive and direct effect on the quality of product at a $95 \%$ reliance level.

\section{Hypothesis 2: Innovation has an effect on the sales process of domestic cosmetics.}

Table 5: Hypothesis 2

\begin{tabular}{||c|c|c||}
\hline Hypothesis 2 & path coefficient & significance coefficient \\
\hline $\begin{array}{c}\text { Innovation has an effect on } \\
\text { the sales process of domestic } \\
\text { cosmetics. }\end{array}$ & 0.67 & 10.48 \\
\hline
\end{tabular}

According to Table 5, it is clear that the path coefficient is 0.67 between innovation and satisfaction with the sales process, something which shows the positive and direct effect of innovation on the quality of product. Moreover, the significance coefficient of these two variables is 10.48 (above 1.96) which indicates that the effect of innovation on satisfaction with the sales process is significant at a 0.05 error level. Therefore, it can be stated that innovation has a positive and direct effect on satisfaction with the sales process at a $95 \%$ reliance level.

Hypothesis 3: Innovation has an effect on the brand of domestic cosmetics. 
Table 6: Hypothesis 3

\begin{tabular}{||c|c|c||}
\hline Hypothesis 2 & path coefficient & significance coefficient \\
\hline $\begin{array}{c}\text { Innovation has an effect on the } \\
\text { brand of domestic cosmetics. }\end{array}$ & 0.84 & 8.89 \\
\hline
\end{tabular}

According to Table 6 , it is clear that the path coefficient is 0.84 between innovation and the brand of cosmetics, something which shows the positive and direct effect of innovation on the brand of cosmetics. Moreover, the significance coefficient of these two variables is 8.89 (below 1.96) which indicates that the effect of innovation on the brand of cosmetics is significant at a 0.05 error level. Therefore, innovation has an effect on the brand of cosmetics.

Hypothesis 4: Innovation has an effect on satisfaction with after-sales services of domestic cosmetics.

Table 7: Hypothesis 4

\begin{tabular}{||c|c|c||}
\hline Hypothesis 2 & path coefficient & significance coefficient \\
\hline Innovation has an effect on & & 11.05 \\
satisfaction with after-sales & 0.64 & \\
services of domestic cosmetics. & & \\
\hline
\end{tabular}

According to Table 7, it is clear that the path coefficient is 0.64 between innovation and satisfaction with after-sales services, something which shows the positive and direct effect of innovation on satisfaction with after-sales services. Moreover, the significance coefficient of these two variables is 11.05 (above 1.96) which indicates that the effect of innovation on satisfaction with after-sales services is significant at a 0.05 error level. Therefore, it can be stated that innovation has a positive and direct effect on satisfaction with after-sales services of cosmetics at a $95 \%$ reliance level.

\section{DISCUSSION ON THE RESULT OF THE RESEARCH ANALYSIS}

In total, the research hypotheses were evaluated. It is now clear that the path coefficients between innovation (independent variable) and the quality of product, satisfaction with the sales process, satisfaction with after-sales process, and the brand of product (dependent variables) were $0.63,0.67,0.84$ and 0.64 . Furthermore, the significance coefficients between innovation and the quality of product, satisfaction with the sales process, satisfaction with after-sales process, and the brand of product were 10.96, 1048, 8.89, and 11.05. Therefore, the effects of innovation on the quality of product, satisfaction with the sales process, satisfaction with after-sales services, and the brand of product were confirmed. In total, it can be reasoned that the positive and direct effect of innovation on customer satisfaction was confirmed at a 95\% reliance level.

The structural equation modeling technique was used to test the hypotheses. The output of LISREL indicated that the structural model was fitted for testing hypotheses (the ratio of $x^{2} / d f$ is below 3 ). The value of RMSEA was equal to 0.059 which shows the appropriateness of fitness model. The value of $x^{2}$ is 266.12, and the degree of freedom is 117 resulting from division of them below 3, something which shows a very appropriate goodness of fit. In other words, the observed data are consistent with the research conceptual model to a great extent. The values of GFI, AGFI, NFI, CFI, IFI and RFI are 0.93, $0.92,0.94,0.96,0.94$, and 0.93 , respectively. They show the appropriate goodness of fit.

Table 8: The Indicators of Goodness of Fit

\begin{tabular}{|c|c|c|c|c|c|c|c|c|c||}
\hline \hline Indicator & $x^{2} / d f$ & p-value & RMSEA & NFI & CFI & IFI & RFI & GFI & AGFI \\
\hline Allowed Value & $<3$ & $<0.05$ & $<0.08$ & $>0.9$ & $>0.9$ & $>0.9$ & $>0.9$ & $>0.9$ & $>0.9$ \\
\hline Value & 2.314 & 0.0000 & 0.055 & 0.94 & 0.96 & 0.94 & 0.93 & 0.93 & 0.92 \\
\hline
\end{tabular}




\section{CONCLUSION}

Nowadays managing customer relation is an essentiality of activities which improves the supply chain of an organization. Therefore, customer satisfaction is regarded as a key element, and the quality of products is considered vital for the survival and profitability of an organization. Customer satisfaction is one of the strategic categories for organizations, especially the industries. If the competition in the industry becomes more intense, customers should be able to bargain more. One of the ways of satisfying customers is to bring innovation to the process of production and sales of products. Accepting innovation requires a change in the paradigm of innovation. One of these changes is to convert the closed boundaries of an organization into penetrable shells, something which makes innovation flow more easily between the external environment and the internal innovation process of a company. Another change is to integrate the external knowledge sources completely; however, the internal knowledge base should be strengthened first.

This study was intended to investigate the effect of innovation of customer satisfaction (the quality of product, satisfaction with sales, satisfaction with after-sales services, and the brand of product). The results of analyses are as follows:

According to the findings (path coefficient: 0.81 and significance coefficient: 11.64), innovation has an effect on customer satisfaction. Therefore, innovation (open or closed) has a direct and positive relationship with customer satisfaction (the quality of product, satisfaction with sales, satisfaction with after-sales services, and the brand of product). In other words, more innovations improve customer satisfaction.

According to the results of data analysis, it was confirmed that innovation had a positive and direct effect on the quality of product (path coefficient: 0.63 and significance coefficient: 10.96) therefore, innovation can improve the quality of product.

The research results indicated that innovation had a positive and direct effect on satisfaction with the sales processes of cosmetics (path coefficient: 0.67 and significance coefficient: 10.48); therefore, innovation in the sales process can satisfy customers.

According to the research results, innovation had an effect on the brand of cosmetics (path coefficient: 0.84 and significance coefficient: 8.89 ), something which means innovation in products will make them known as a brand.

The research results indicated that innovation had an effect on satisfaction with after-sales services of cosmetics (path coefficient: 0.64 ad significance coefficient: 11.05). Therefore, the implementation of open and closed innovations in after-sales services could satisfy customers with the products manufactured by cosmetics companies. 


\section{REFERENCES}

[1] Ades, C., Figlioli, A., Sbragia, R., Porto, G., Plonski, G., Celadon, K. (2013). Implementing open innovation: The case of Natura, IBM and siemens. Journal of Technology Management \& Innovation, 8, 12-25.

[2] Baldassarre, B., Calabretta, G., Bocken, M, N., Jaskiewicz, T. (2017). Bridging sustainable business model innovation and user-driven innovation: A process for sustainable value proposition design, Journal of Cleaner Production, 147, 175-186

[3] Barasa, L., Knoben, J., Vermeulen, P., Kimuyu, P, Kinyanjui, B. (2017). Institutions, resources and innovation in East Africa: A firm level approach Research Policy, 46(1), 280-291.

[4] Buijs, J. (2007). Innovation leaders should be controlled schizophrenics Creativity and Innovation Management, 16(2), 203-210.

[5] Castellacci, F., Natera, M, J. (2011). The dynamics of national innovation systems: a panel cointegration analysis of the coevolution between innovative capability and absorptive capacity. ,http://mpra.ub.unimuenchen. de/31583/1/MPRA_paper_31583.pdf.

[6] Chesbrough, H., Chesbrough, H., Vanhaverbeke, W., West J. (2006). Open innovation: A new paradigm for understanding industrial innovation. In Open Innovation: Researching a new paradigm. Oxford University Press.

[7] Dahlander, L., Gann, D.(2007). Appropriability, proximity, routines and innovation: How open is open innovation?, Paper presented at the Druid Summer Conference 2007, 34.

[8] Dvořáková, L., Faltejsková, O. (2016). Development of Corporate Performance Management in the Context of Customer Satisfaction Measurement, Social and Behavioral Sciences, 230, 335-342.

[9] Elad, H, E., Koski, H. (2010). Applying open innovation in business strategies: Evidence from Finnish software firms, Research Policy, 39(3), 351-359.

[10] Galloway, T., Miller, R, D., Sahaym, A., Arthurs, D, J. (2017). Exploring the innovation strategies of young firms: Corporate venture capital and venture capital impact on alliance innovation strategy, Journal of Business Research, 71, 55-65.

[11] Gerke, A., Dickson, G., Desbordes, M., Gates, S. (2017). The role of interorganizational citizenship behaviors in the innovation process, Journal of Business Research, 73, 55-64.

[12] Ghosh, A., Kato, T., Morita, H. (2017). Incremental innovation and competitive pressure in the presence of discrete innovation, Journal of Economic Behavior \& Organization, 135, 1-14.

[13] Girgenti, A., Pacifici, B., Ciappi, A., Giorgetti, A. (2016). An Axiomatic Design Approach for Customer Satisfaction through a Lean Start-up Framework, Procedia CIRP, 53, 151-157.

[14] Gundy, G., Lusoy, G., Kilic, K., Alpkan, L. (2011). Effects of Innovation Types on Firm Performance. International Journal of Production Economics, 133(2): 662-676.

[15] Hamdani, J. Wirawan, C. (2012). Open Innovation Implementation to Sustain Indonesian SMEs, Procedia Economics and Finance, 4, 223-233.

[16] Iberahim, H., Taufik, M., Adzmir, M., Saharuddin, H. (2016). Customer Satisfaction on Reliability and Responsiveness of Self Service Technology for Retail Banking Services, Economics and Finance, 37, 13-20.

[17] Lazzarotti V, Manzini, R. (2009). Different modes of open innovation: A theoretical framework and an empirical study. International Journal of Innovation Management 2009. 13 (4), 615-636.

[18] Ling, M, G., Fern, S, Y., Boon, K, L., Huat, S, T. (2016). Understanding Customer Satisfaction of Internet Banking: A Case Study In Malacca, Economics and Finance, 37, 80-85. 
[19]Lun, V, H, Y., Shang, C, K., Lai, H, K., Cheng, E, C,T. (2016). Examining the influence of organizational capability in innovative business operations and the mediation of profitability on customer satisfaction: An application in intermodal transport operators in Taiwan, International Journal of Production Economics, 171(2), 179-188.

[20] Maurya, K., Mishra, P., Anand, S., Kumar, N. (2015). Corporate identity, customer orientation and performance of SMEs: Exploring the linkages, IIMB Management Review, 27(3), 159-174.

[21] Monsef S, Ismail W.K.W. (2012). The impact of open innovation in new product development process. International Journal of Fundamental Psychology \& Social Sciences, 2(1), 7-12.

[22] Mortara, L., Napp, J., Slacik, I., Minshall T. (2009). How to implement open innovation: Lessons from studying large multinational companies. University of Cambridge.

[23] Navimipour, J, N., Soltani, Z. (2016). The impact of cost, technology acceptance and employees' satisfaction on the effectiveness of the electronic customer relationship management systems, Computers in Human Behavior, 55, 1052-1066.

[24] Pulles, J, N., Schiele, H., Veldman, J., Hüttinger, L. (2016). The impact of customer attractiveness and supplier satisfaction on becoming a preferred customer, Industrial Marketing Management, 54, 129-140.

[25]Saebi, T. Foss, N. (2016). Business models for open innovation: Matching heterogeneous open innovation strategies with business model dimensions, European Management Journal, 33(3), 201-213.

[26] Spithoven, A. ,Clarysse, B. and Knockaert, M.(2010). Building absorptive capacity to organize inbound open innovation in traditional industries. Technovation, 30 (2), 130-141.

[27] Trejo, M, J., Gutiérrez, S, J., Guzman, M, G. (2016). The customer knowledge management and innovation, Contaduría y Administración, 61(3), 456-477.

[28] Vanhaverbeke W. (2006). The inter-organizational context of open innovation. In Chesbrough H, Vanhaverbeke W, \& West J. (eds), Open Innovation: Researching a new paradigm. Oxford University Press.

[29] Waiyawuthanapoom N, Isckia T, Danesghar F. (2013). Ready for open innovation or not? An open innovation readiness assessment model (OIRAM). Proceeding of the International Conference on Intellectual Capital; Washington, USA, October 24-25.

[30] Wang, Q., Zhao, X., Voss, C. (2016).Customer orientation and innovation: A comparative study of manufacturing and service firms, International Journal of Production Economics, 171(2), 221-230.

[31] Wang, Y., Hsiao, H, S., Yang, Z., Hajli, N. (2016). The impact of sellers' social influence on the co-creation of innovation with customers and brand awareness in online communities, Industrial Marketing Management, 54, 56-70.

[32] Yuhan, Y., Yun, Z. (2009). Measuring and analyzing the continued innovation capability in Guizhou Huagong Tools Company. University of gavle. Department of technology and built environment.

[33] Zain, M, O., Saidu, B, M. (2016). The Customers Satisfaction on Retailers' Brand Products: A Study on Selected Areas in Klang Valley, Economics and Finance, 35, 418-427.

[34]Zubizarreta, M., Cuadrado, J., Iradi, J., García, H., Orbe, A. (2017). Innovation evaluation model for macro-construction sector companies: A study in Spain, Evaluation and Program Planning, 61, 22-37.

\section{Article history:}

- $\quad$ Received 18 April 2017

- Accepted 5 June 2017 